is medical practice? Does, then, the Obstetrical Society "certify unqualified practitioners" and does the General Medical Council recognise such unqualified practitioners as being "competent in branches of medical practice" ? Is it, then, accurately asserted that this Council "recommended to the Privy Council provisions to legalise the practice of midwifery by persons not medically educated"?

Right or wrong, then, it is difficult to get further than to convict the General Medical Council of the opinion that a woman who attends on a physiological condition is not a medical practitioner. However, this unhappy Council has other sins to answer for. But first, is "its form of return of its corporate members" illegal? Did it at any time maintain this illegality wilfully - that is to say, recognising it to be illegal? Did it thereby "conspire to deprive" anybody of anything? Can a Council, then, conspire by itself or did the gentleman mean that the members of the Council did illegally conspire among themselves? Is there no remedy for conspiracy, and is there any preliminary necessity for proving the offence? Is it worth while to continue?

There may be various opinions as to the present state of the common midwife-as to the ignorance of some, as to the iniquities of a few, and as to the remedy for certain evils. There may be two opinions as to the wisdom of the Obstetrical Society's remedy, or as to any other remedy, or as to what course the General Medical Council should take. But to take it for proved that to nurse a parturient woman is medical practice, to allege that selling spectacles is surgery, to say that he who certifies the followers of either calling to understand their business does thereby "cover" them, is a mere abuse of language. To demand that the General Medical Council shall do the impossible-namely, that it shall satisfy the demands of the Corporate and Medical Reform Association-or to shriek for Parliamentary compulsion that every labour shall be attended by a registered practitioner, regardless that the world did for a time, and in some part does still, after a fashion get through the matter without such aid, is simply to render ridiculous the profession which is alleged to make any such demands.

These Hotspurs of the North appear to have forgotten that they so far resemble the Sabbath Day, that the public is not made for them but they for the public, and that mere abuse of the General Medical Council, however exciting, does no good, but alienates support from projects so frantically advocated. If we are to secure the reforms which we all recognise as needful it is first necessary to provide ourselves with sound and rational arguments and we must advance them with moderation. There cannot be two opinions as to the usefulness of shouting arguments which are too rotten to hold together. I am, Sirs, yours faithfully,

Frant, Sussex, Nov. 6th, 1899.

HaMilton HaLl.

\section{"PRACTICAL PATRIOTISM."} To the Editors of THW LANCET.

SIRs,-I hope I may be allowed to suggest that we should all undertake to attend the wives and children of the men on active service without charging any fees.

I am, Sirs, yours faithfully,

Buckingham, Nov. 9th, 1899.

Georga H. DE'Ath.

** A similar suggestion was made in our columns on Oct. 28th by Dr. Robert Hugh Hodgson.-ED. L.

\section{"THE EXPENSES OF A MEDICAL MAN'S MOTOR-CAR." To the Editors of THE LANCET.}

SIRs,-Grant me a small amount of space to assure Dr. Charpentier that I had not the smallest intention, either "by implication" or otherwise, of casting any doubts on his accounts. I had not Dr. Charpentier's letter before me when I wrote nor was it at all in my mind. I simply wrote "at large," as the Highland chieftain swore, giving my experiences and impressions for what they were worth. As to my conclusions, well, they are the result of my experience. Dr. Charpentier's are the result of his. Both may be of use to those who are thinking of buying a motor-car. It is hardly matter of wonderment if our experiences are not identical. But, really, I fancy that very few busy practitioners could view with equanimity the prospect of spending "many happy hours" on their backs under their motor-cars when work and duty were loudly clamouring for their presence elsewhere. For nyself I never attempt it. When the time comes for spending the " happy hours" I send for someone to spend them, and send for a cab or get upon a horse and go about my business Most practitioners who might be called upon to undertake "a day's round of over 30 miles" would have to adopt the same course. My car is at present suffering from severe general debility and the consultant is coming over to-morrow to perform an operation. I shall have two horses out. That is where the (?) as to the "economy" comes in.

I am, Sirs, yours faithfully,

Stratford-on-Avon, Nov. 10th, 1899.

HARRY LUPTON.

\section{"THE ORGANISATION OF THE PROFESSION."}

\section{To the Editors of THE LANCET.}

SIRS,-As I am the source whence THE LANCET Special Commissioner obtained his information concerning the Ashton-under-Lyne and District Medical Society may I be allowed to say a few words in explanation of the points to which your correspondent, "Practitioner," has called atten. tion in THE LANCET of Nov. 11th? From what I know of clubs I am confident that he must have clubs of a very exceptional character. Apparently they consist only of males. The bulk of the clubs in this district-and in Denton practically all the practice is club practice-consist for the most part of women and children, so that their possession by a practitioner means that he will bave a larger amount of work from them proportionally to the membership than your correspondent calculates, and this would very materially alter his returns. Again, he is entirely mistaken in thinking that people who can pay more than the ordinary - that is, minimum-fees of the district will not join clubs. The correspondence I have recently had with men in widely-separated districts in connexion with the Medical Guild scheme has shown me that this is the bane of club practice in most parts of the country. Does your correspondent imagine that this universal. demand for a wage-limit can be due to anything else than abuse of clubs in this way? And really one need not be surprised that they are abused. Have we not as a nation been acting on the plan of buying in the cheapest market and selling in the dearest for several generations past? And by what law can we medical men hope to escape the effects of this habit on the part of the public? I know of none. I do not see that club practice in itself is at all derogatory to the profession so long as it is remunerative enough; but in the past clubs have been managed by the laity and it is not to be wondered at that they have managed them to their own advantage and have gradually forced prices down by pitting medical men against one another. If we are to have clubs they should be managed by the profession entirely and a proper wage-limit fixed, and it was to secure this that I took the initiative in having a scheme to effect this discussed by the Ashton Society, and although we are not threatened by clubs in Ashton I am convinced that it would have paid us to have adopted the scheme.

The next point to which your correspondent alludes is our system of fees. When our society was commenced we decided that, for the present at any rate, it would not be advisable to make any great alteration in existing rates, and all that was done therefore was to adopt the scale that was most in use. Very few men were charging on exactly the same scale, so that to get uniformity was no easy matter, and indeed slight differences still prevail. Is "Practitioner" right in describing as the old system that in which medical men charged a definite fee per visit irrespective of whether medicines, \&c., were supplied or not? If so, it is so old in this district that the memory of its having ever existed has completely disappeared. The adoption of this system was discussed by us when we formed our societs and we concluded that it would be too great an innovation; we deemed it of more importance to get the men together and united than to fix an ideal tariff. When we are thoroughly united the fees can very soon be put upon a more rational basis. Regarding the midwifery fee, old inhabitants have repeatedly told me that they never used to pay more than $10 \mathrm{~s} .62$. It was raised to the present point years before I came to the town. A fee of $1 \frac{1}{2}$ guineas is an impossibility 